\title{
Copepod egg production in Long Island Sound, USA, as a function of the chemical composition of seston
}

\author{
Sigrún Huld Jónasdóttir*, David Fields, Silvio Pantoja \\ Marine Sciences Research Center, State University of New York at Stony Brook, Stony Brook, New York 11794-5000, USA
}

\begin{abstract}
The effect of the chemical composition of seston on the egg-production rates ( $E_{\mathrm{r}}$ : eggs female $\mathrm{d}^{-1}$ ) of the copepods Acartia hudsonica Pinhey and Temora longicornis (Müller) was studied in Long Island Sound, USA, $\left(41^{\circ} 00^{\prime} \mathrm{N}, 73^{\circ} 05^{\prime} \mathrm{W}\right)$ during spring 1990 . The seston was analyzed for carbon, nitrogen, protein, carbohydrate $(\mathrm{CHO})$ and fatty acid content as well as chlorophyll (chl) and ciliate concentrations. Principal component analysis (PCA) revealed significant correlations [score $>0.7$ on a same principal component ( $\mathrm{PC}$ ] between in situ $E_{\mathrm{r}}$ of the 2 copepod species and the chemical composition of the seston. Protein, $\mathrm{CHO}$ and specific fatty acids correlated strongly with $E_{\mathrm{r}}$ of $A$. hudsonica (CHO negatively). The same components were moderately correlated (score $>0.6$ on a same PC) with the $E_{\mathrm{r}}$ of $T$. longicornis. The fatty acid requirements of $A$. hudsonica and $T$. longicornis were for high $\omega 3: \omega 6$ ratios and low $20: 5$ to $22: 6$ ratios. The fatty acid $22: 6 \omega 3$ was also correlated with $E_{\mathrm{r}}$ of both species. The concentration of ciliates and the $C: N$ ratio of seston did not affect $E_{\mathrm{r}}$ of any of the species under any condition. Path analysis models were composed to evaluate the important mechanisms controlling the $E_{\mathrm{r}}$ observed in this study. The analysis demonstrated the strength and importance of indirect relationships that were not apparent from conventional correlation statistics. The results from 4 path analysis models showed that chl and ciliates exert an important control on natural egg production rates, through their chemical composition, despite the fact that linear correlations between phytoplankton and ciliates and $E_{\mathrm{r}}$ were not significant.
\end{abstract}

KEY WORDS: Acartia $\cdot$ Temora Egg production · Food quality Spring bloom - Path analysis

\section{INTRODUCTION}

Biological and physical factors that influence the egg-production rates $\left(E_{\mathrm{r}}\right.$ : eggs female $\left.\mathrm{e}^{-1} \mathrm{~d}^{-1}\right)$ of copepods have been widely studied in the marine environment. Several studies report strong correlations between the standing stock of phytoplankton, measured as chlorophyll (chl) a concentration, and $E_{\mathrm{r}}$ of copepods (e.g. Checkley 1980, Uye 1981, Durbin et al. 1983, Runge 1985b) while others find no correlation between the 2 factors (e.g. Runge 1985a, Stearns et al. 1989, Durbin et al. 1992, Kleppel 1992). In Long Island

\footnotetext{
- Present address: Danish Institute for Fisheries and Marine Research, Charlottenlund Castle, DK-2920 Charlottenlund, Denmark
}

Sound (LIS), USA, it has been observed that phytoplankton blooms do not necessarily result in enhanced egg production of the copepods Acartia hudsonica (Weissman et al. 1993), T. longicornis and Centropages typicus (W. T. Peterson pers. comm., unpubl, data). The composition of the seston was not studied in those investigations.

In addition to chl concentrations, in situ egg-production studies to date have mainly measured correlation between $E_{\mathrm{r}}$ of copepods and microzooplankton concentrations (White \& Roman 1992, Kiørboe \& Nielsen 1994), carbon, nitrogen and $\mathrm{C}: \mathrm{N}$ ratios (Durbin et al. 1983, Ambler 1986, Kleppel 1992, White \& Roman 1992). The effects on copepod $E_{\mathrm{f}}$ of other chemical components of seston such as fatty acids, carbohydrates $(\mathrm{CHO})$ and proteins which are also known to fluctuate with seasons and during individual blooms 
(Morris et al. 1983, Mayzaud et al. 1989) have not been examined in detail before.

The objective of the study presented here was to define the qualitative and quantitative relationship between food and $E_{\mathrm{r}}$ of 2 coastal copepod species, Acartia hudsonica Pinhey and Temora longicornis (Müller) in LIS during a spring phytoplankton bloom in order to understand the observed lack of correlation between copepod egg production and phytoplankton standing stock. Along with temperature measurements, chl a concentration, as an indicator of phytoplankton biomass, and ciliate density, as well as the chemical composition (protein, $\mathrm{CHO}$ and fatty acid content) of the seston were measured. Although this study focused on the specific fatty acids (SpFA) of the seston but did not further separate protein and $\mathrm{CHO}$ into specific compounds, the importance of other specific components of the phytoplankton cells, such as amino acids and vitamins (Conklin \& Provasoli 1977. Dadd 1982, Harrison 1990), should not be ignored.

In this paper, the plausible interactions between food and egg production were tested by the use of path analysis because the use of path analysis can yield insight into the interactions of variables in cases where direct or indirect causal paths are likely to be important (Li 1975). Path analysis is a form of structural linear regression analysis (Li 1975, Sokal \& Rohlf 1981) that uses a diagram, structured by the investigator, to form logical causal relationships among variables that are compatible with the data ( $\operatorname{Li} 1975$ ).

This study investigates in more detail than previously done, the relationship between the chemical composition of particulate organic matter (POM) and in situ $E_{\mathrm{r}}$ of copepods in the marine environment.

\section{METHODS}

Zooplankton sampling and egg production. Copepods were collected with a $210 \mu \mathrm{m}$ mesh-size plankton net from LiS off Port Jefferson, New York $\left(41^{\circ} 00^{\prime} \mathrm{N}\right.$, $73^{\circ} 05^{\prime} \mathrm{W}$ ) on 5 dates (February 22, and March 2, 8, 16 , and 23) during spring 1990. The net was towed vertically by hand from a depth of $\sim 25 \mathrm{~m}$. The contents of the cod end were carefully emptied into a bucket filled with ambient seawater and transported to the laboratory. Immediately after arrival at the laboratory $(\sim 2 \mathrm{~h}$ after sampling), actively swimming Acartia hudsonica and Temora longicornis females were sorted out for use in incubation experiments to measure $E_{\mathrm{r}}$.

Females were incubated in 11 polycarbonate bottles. For each copepod species, 4 to 5 bottles containing 3 to 4 females each were set up. Bottles were filled with $100 \mu \mathrm{m}$ screened ambient water from $\sim 5 \mathrm{~m}$ depth. Screening of the water removed all nauplii, cope- podites and adult copepods but allowed larger phytoplankton cells and chain forms to be retained in the incubation water. To correct for eggs which may have passed through the $100 \mu \mathrm{m}$ screening of the incubation water, 2 to 3 controls were set up.

Bottles were incubated for $24 \mathrm{~h}$ at ambient LIS temperatures on a $14 \mathrm{~h}$ dim light: $10 \mathrm{~h}$ dark cycle. The contents were then screened using a $20 \mu \mathrm{m}$ mesh and the eggs counted. The eggs of Acartia hudsonica and Temora longicornis were easily distinguished from each other as the eggs of $A$. hudsonica are translucent where $T$. longicornis eggs are dark (greenish grey). The number of eggs of each species in the control 3 to 9 eggs $1^{-1}$ ) were subtracted from the in situ egg-production counts. The prosome length of the females was measured at the end of all incubations.

Sampling and measurements of seston. Concurrent with the zooplankton sampling, water was pumped from 5 and $15 \mathrm{~m}$ depths for various measurements of seston. Temperature was measured with a mercury thermometer with a division of $0.1^{\circ} \mathrm{C}$. Duplicates of $100 \mathrm{ml}$ samples were taken for determination of phytoand microzooplankton composition and were fixed immediately with Lugol's solution. All other water samples were stored in bottles on ice in coolers until filtered in the laboratory, usually 2 to $3 \mathrm{~h}$ after sampling. The water was passed through a $100 \mu \mathrm{m}$ screen before all filtrations in order to remove larger animals (copepods, jellyfish, etc.). Samples for both total chl a (GF/F filters) and the $>8 \mu \mathrm{m}$ (Nuclepore) chl a fraction were filtered ( 2 to 3 replicate samples each) and the concentrations used to estimate the standing stock of phytoplankton. Duplicate samples for carbon and nitrogen were filtered on combusted GF/F filters and dried at $60^{\circ} \mathrm{C}$. Triplicate $1 \mathrm{l}$ samples for each of the protein, lipid and $\mathrm{CHO}$ analyses of POM were filtered onto ignited $\mathrm{GF} / \mathrm{C}$ filters. Individual filters were folded and put into $2 \mathrm{ml}$ cryogenic vials. Samples were immediately frozen at $-80^{\circ} \mathrm{C}$ for later chemical analysis.

Ciliates were counted from a $1 \mathrm{ml}$ condensed Lugol's sample using a Sedgewick Rafter counting cell. Estimation of volume concentrations of ciliates was performed by filtering a known volume of the Lugol's sample onto a $0.25 \mu \mathrm{m}$ Nuclepore filter, which was put on a microscope slide and covered with an oil drop and a cover slide. The sample was immediately analyzed under an inverse compact microscope by measuring $>10$ of the most abundant ciliates and all of the lesser abundant ciliate types. Volumes were calculated from measurements of linear dimensions using simple geometric formulas corresponding to the shapes of the ciliates.

Chemical analysis of seston. Proteins were determined using bicinchoninic acid (BCA) protein assay reagent (Pierce) (Smith et al. 1985). Protein was solubi- 
lized from the particles on the filters using $1 \%$ sodium dodecyl sulfate (lauryl) detergent prior to analysis. The light extinction of the protein solution was quantified on a spectrophotometer at a wavelength of $562 \mathrm{~nm}$. CHO was measured by the 3-methyl-2-benzothiazolinone hydrazone hydrochloride (MBTH) assay described by Burney \& Sieburth (1977), Johnson \& Sieburth (1977) and Johnson et al. (1981). The light extinction of the CHO solution was measured at $635 \mathrm{~nm}$ on a spectrophotometer. The MBTH method used on phytoplankton cultures in a concurrent laboratory study (Jónasdóttir 1994) was found to give levels per cell about 2 times lower than those reported in the literature for similarly sized cells. However, as the method gives a good linearity with increasing concentration of standards, the relative change in $\mathrm{CHO}$ concentration among dates can be used in correlation with $E_{\mathrm{r}}$. Carbon and nitrogen content of the samples were measured on a Perkin Elmer 240 B elemental analyzer.

Fatty acids were analyzed by gas chromatography on a capillary column following standardized methods of fatty acid analysis as described by Peltzer et al. (1984) and Wakeham \& Canuel (1990). Lipids were extracted by ultra-sound sonication into $\mathrm{CH}_{2} \mathrm{Cl}_{2}$ : methanol $(2: 1, v / v)$ and the fatty acids trans-methylated with $\mathrm{BF}_{3}$-methanol to form fatty acid methyl esters (FAME). The FAME fraction was purified and separated from the other lipid compound classes on a short, fully activated silica gel column (Peltzer et al. 1984). The samples were analyzed on a gas chromatograph (Carlo Erba 2150) using hydrogen as a carrier gas at $0.8 \mathrm{~kg} \mathrm{~cm}^{-2}$. The temperature program was increased from 100 to $230^{\circ} \mathrm{C}$ in $3 \mathrm{~min}$, and then remained isothermal at $230^{\circ} \mathrm{C}$ for $15 \mathrm{~min}$. Peaks from chromatograms were compared to SUPELCO FAME I and II standards for specific fatty acid identification and the integrated peaks of each fatty acid compared to the peak area of a $C_{19}$ internal standard of a known concentration. A detailed description of each of the chemical analyses is outlined in Jónasdóttir (1992).

Principal component analysis. Due to the large number of environmental and chemical variables involved in this study, the method of principal component analysis (PCA) was applied to the data set to separate out the variables that were best correlated with the observed $E_{\mathrm{r}}$ in the field. The objective of PCA is to identify principal components that are related and to obtain an overview of similarity among samples without making any a priori assumptions about relationships between variables (Meglen 1992). This method is powerful when dealing with complex and large data bases (Loehlin 1987, Meglen 1992). The analysis was run for $E_{\mathrm{r}}$ and total chl $a$, chl $a>8 \mu \mathrm{m}$, ciliate, protein, $\mathrm{CHO}$ and fatty acid concentrations. Selection of fatty acids for the final run of the PCA was based on a pre-correlation analysis of $E_{\mathrm{r}}$ and fatty acids.

For the purpose of this study, the results of interest lie in the individual principal component (PC) which includes egg production as a major variable. The other variables that, jointly with $E_{r}$ form that $\mathrm{PC}$ are the variables that correlate strongly with $E_{\mathrm{r}}$. A score higher than 0.6 on a component is a moderate loading while a score higher than 0.7 is a significant loading (Meglen 1992). The PCA was run for a correlation matrix in a Varimax rotation mode.

\section{RESULTS}

Throughout the duration of the sampling period the water column was uniform with temperatures at $\sim 4^{\circ} \mathrm{C}$. No differences were observed between variables measured at 5 and $15 \mathrm{~m}$ depth with the exception of ciliate concentration and chl a greater than $8 \mu \mathrm{m}$ size (Fig. 1). Mean values of the other parameters measured at the 2 depths are, therefore, combined in Fig. 1 and in the PCA analysis

As shown by the chl a concentration (Fig. 1a) a bloom had already started by the first sampling date, February 22, and appeared to reach a peak between March 2 and 8 . The bloom had ceased by March 16 , and the chl a concentration remained about the same through the last sampling date, March 23. The composition and size of the phytoplankton present are shown in Table 1 . The bloom consisted primarily of a large diatom species, Rhizosolenia sp., and ca $18 \mu \mathrm{m}$ centric diatom species. The smaller fractions included mainly flagellates. The post-bloom phytoplankton assembly was made up of small round flagellates. Diatoms were also abundant on the last sampling date, March 23, where centric diatom species, less that $8 \mu \mathrm{m}$ in diameter, and the diatom Skeletonema sp. were the dominant forms. Ciliate concentration increased after cessation of the bloom (Fig. 1b), with significantly higher concentrations at $5 \mathrm{~m}$ than at $15 \mathrm{~m}$ depth on the last sampling date, March 23.

Chemical composition of the POM over the sampling period varied for the different components. The particulate organic carbon (POC) and total fatty acids stayed relatively constant the first 3 wk but dropped significantly (Student's $t$-test, $\alpha=0.05$ ) with the cessation of the bloom (Fig. 1c, e). The particulate organic nitrogen (PON) concentration decreased slightly with the bloom progression. Protein peaked during the growth stage of the bloom (March 2) while CHO peaked at the point of highest chl a concentration (March 8). The protein: $\mathrm{CHO}$ and $\mathrm{C}: \mathrm{N}$ ratios (Fig. 1f) were inversely correlated, with the $C: N$ ratio following the chl a concentration. This pattern suggests a recovery in the 

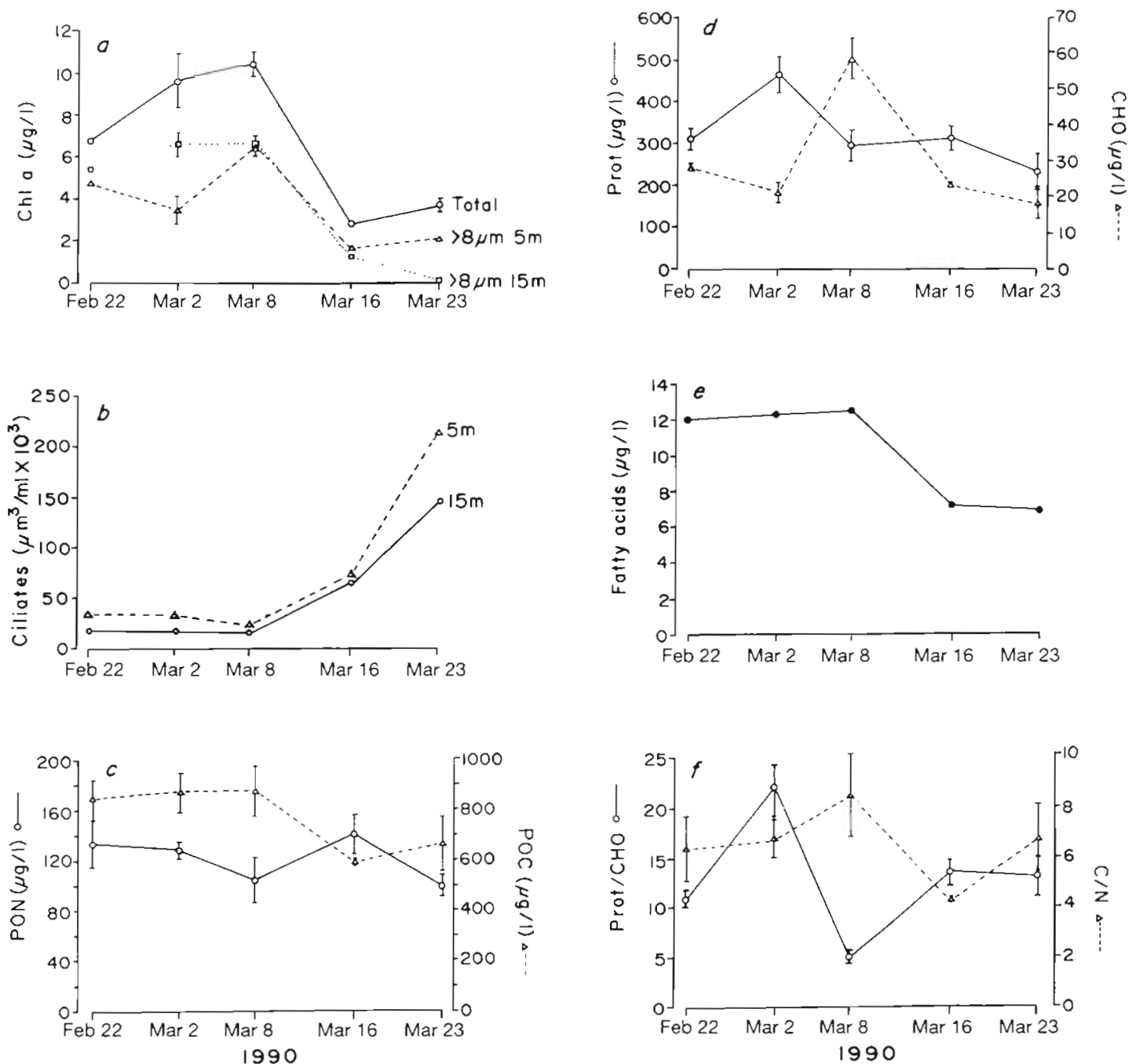

Fig. 1. Concentrations expressed as mean $\pm 1 \mathrm{SD}$ of (a) total chlorophyll $a$ and chl $a>8 \mu \mathrm{m}$ size at 5 and $15 \mathrm{~m}$, (b) ciliates at 5 and $15 \mathrm{~m}$, (c) particulate organic nitrogen (PON) and particulate organic carbon (POC), (d) particulate protein (Prot) and carbohydrates ( $\mathrm{CHO}$ ), (e) total fatty acids, and (f) protein: $\mathrm{CHO}$ and $\mathrm{C}: \mathrm{N}$ ratios in Long Island Sound, USA, during spring 1990. Missing confidence intervals are smaller than the height of the symbol

Table 1. Chlorophyll (chl) concentration in $\mu \mathrm{g}^{-1}$ (mean $\pm 1 \mathrm{SD}$ ) and composition during the sampling period (1990) in Long Island Sound, USA

\begin{tabular}{|crrll|}
\hline Date & Depth & Chl a total & Chl $a>8 \mu \mathrm{m}$ & Major phytoplankton types \\
\hline February 22 & $5 \mathrm{~m}$ & $6.79 \pm 0.18$ & $4.76 \pm 0.09$ & Rhizosolenia \\
& $15 \mathrm{~m}$ & $6.81 \pm 0.12$ & $5.46 \pm 0.00$ & Rhizosolenia + small flagellates \\
March 2 & $5 \mathrm{~m}$ & $9.94 \pm 0.97$ & $3.50 \pm 1.37$ & Rhizosolenia + centric diatoms \\
& $15 \mathrm{~m}$ & $9.32 \pm 2.81$ & $6.66 \pm 0.97$ & Rhizosolenia + centric diatoms \\
March 8 & $5 \mathrm{~m}$ & $10.29 \pm 0.56$ & $6.30 \pm 0.20$ & Rhizosolenia \\
& $15 \mathrm{~m}$ & $10.57 \pm 0.74$ & $6.54 \pm 0.30$ & Rhizosolenia + small flagellates \\
March 16 & $5 \mathrm{~m}$ & $2.83 \pm 0.05$ & $1.69 \pm 0.18$ & Round flagellates \\
& $15 \mathrm{~m}$ & $2.80 \pm 0.09$ & $1.30 \pm 0.54$ & Round flagellates \\
March 23 & $5 \mathrm{~m}$ & $3.83 \pm 0.18$ & $2.11 \pm 0.00$ & Centric diatoms \\
& $15 \mathrm{~m}$ & $3.53 \pm 0.37$ & $0.15 \pm 0.03$ & Chain forming diatoms \\
\hline
\end{tabular}


nutrient status of the cells after cessation of the bloom. The fatty acid concentrations of the POM are given in Table 2. Total fatty acid concentration stayed high and constant during the bloom (Table 2, Fig. 1e), and the fatty acids throughout the bloom were dominated by $C_{16}$ fatty acids while the relative contribution of $C_{18}$ fatty acids increased slightly after the bloom (Fig. 2).

$E_{r}$ of both copepod species tested exhibited similar patterns (Fig. 3). They were highest on February 22 and decreased as the bloom progressed. Egg production reached a minimum at maximum chl a concentrations. The $E_{\mathrm{r}}$ of Acartia hudsonica increased slightly but significantly (Student's $t$-test, $\alpha=0.05$ ) between March 8 and 23 while the $E_{\mathrm{r}}$ of Temora longicornis did not increase for the 2 final sampling dates. The prosome length of the species did not differ significantly among the sampling dates ( 1 -way ANOVA, $\alpha=0.05$ ). The prosome lengths were $0.976 \pm 0.049 \mathrm{~mm}$ and $1.246+$

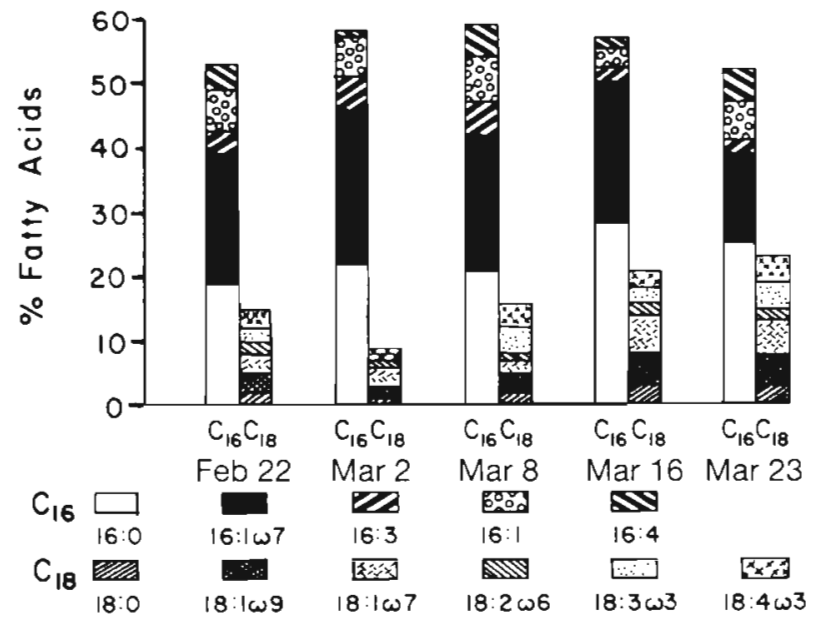

Fig. 2. Percent contribution and composition of the $\mathrm{C}_{16}$ and $\mathrm{C}_{18}$ fatty acids in particulate organic matter (POM) from Long Island Sound during spring 1990

Table 2. Fatty acid concentrations of the particulate organic matter (ng $\mathrm{l}^{-1}$ ) in Long Island Sound during spring 1990. SAFA: saturated fatty acids; MUFA: monosaturated fatty acids; PUFA: polyunsaturated fatty acids;

\begin{tabular}{|c|c|c|c|c|c|}
\hline Fatty acids & Feb 22 & Mar 2 & Mar 8 & Mar 16 & Mar 23 \\
\hline $14: 0$ & 1935.24 & 1941.09 & 891.84 & 681.44 & 1071.97 \\
\hline $15: 0$ & 168.51 & 158.96 & 97.05 & 86.44 & 89.90 \\
\hline $16: 0$ & 2295.47 & 2670.53 & 2587.05 & 1983.38 & 1686.49 \\
\hline $16: 1$ & & & 389.54 & 149.27 & 272.69 \\
\hline $16: 1 \omega 7$ & 2426.20 & 2957.26 & 2648.15 & 1588.62 & 992.61 \\
\hline $16: 1 \omega 9 ?$ & 746.95 & 761.21 & 907.71 & 249.85 & 436.32 \\
\hline $16: 2$ & 113.46 & & & & \\
\hline $16: 3$ & 536.03 & 569.68 & 636.36 & 131.10 & 155.79 \\
\hline $16: 4$ & 302.83 & 189.23 & 145.32 & & \\
\hline Unknown & 571.33 & 200.13 & 418.96 & & 93.63 \\
\hline Unknown & & 140.26 & 178.20 & & \\
\hline $18: 0$ & 243.83 & 151.36 & 221.67 & 210.27 & 189.12 \\
\hline $18: 1 \omega 7$ & 350.54 & 211.80 & 336.80 & 379.17 & 313.89 \\
\hline $18: 1 \omega 9$ & 373.96 & 399.97 & 199.37 & 417.31 & 342.90 \\
\hline $18: 2 \omega 6$ & 156.03 & 134.95 & 190.23 & 148.51 & 142.32 \\
\hline \multicolumn{6}{|l|}{$18: 3 \omega 6$} \\
\hline Unknown & & & & 127.16 & \\
\hline $18: 3 \omega 3$ & 240.42 & & 508.04 & 142.64 & 260.12 \\
\hline $18: 4 \omega 3$ & 373.81 & 306.65 & 552.90 & 203.17 & 305.21 \\
\hline Unknown & 133.02 & 128.09 & 114.54 & 61.00 & 86.51 \\
\hline $20: 1$ & 145.09 & & 201.84 & & \\
\hline $20: 4 \omega 6$ & 81.23 & & & & \\
\hline $20: 5 \omega 3$ & 555.92 & 542.53 & 470.07 & 326.13 & 218.32 \\
\hline $22: 1$ & 79.19 & 189.47 & 384.75 & 72.77 & \\
\hline \multicolumn{6}{|l|}{$22: 4 \omega 6$} \\
\hline $22: 6 \omega 6$ & & & 167.11 & & \\
\hline $22: 6 \omega 3$ & 257.98 & 675.52 & 222.28 & 196.04 & 167.93 \\
\hline Total & 12087.05 & 12328.69 & 12469.78 & 7154.27 & 6825.71 \\
\hline SAFA & 4643.06 & 4921.94 & 3797.61 & 2961.53 & 3037.48 \\
\hline MUFA & 4121.94 & 4519.71 & 5068.15 & 2856.98 & 2358.41 \\
\hline PUFA & 2617.70 & 2418.56 & 2892.32 & 1147.59 & 1249.69 \\
\hline$\omega 3$ & 1428.13 & 1524.70 & 1753.29 & 867.98 & 951.58 \\
\hline$\omega 6$ & 237.25 & 134.95 & 357.34 & 148.51 & 142.32 \\
\hline$\omega 3 / \omega 6$ & 6.02 & 11.30 & 4.91 & 5.84 & 6.69 \\
\hline $20: 5 / 22: 6$ & 2.15 & 0.80 & 2.11 & 1.66 & 1.30 \\
\hline
\end{tabular}

$0.055 \mathrm{~mm}$ for A. hudsonica and T. longicornis respectively.

The composition of the principal components are shown in Fig. 4 for Acartia hudsonica and Temora longicornis. Egg production of A. hudsonica contributed significantly to $\mathrm{PC} 2$, which consisted of the 18:2w6 fatty acid, the $\omega 6$ type fatty acids (originating predominantly from the

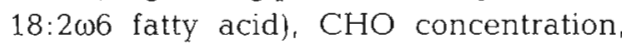
(all inversely correlated with $E_{\mathrm{r}}$ ), the 14:0 fatty acid, $\omega 3: \omega 6$ fatty acid ratio, protein: $\mathrm{CHO}$ ratio, protein and the 22:6w3 fatty acid concentrations. The $E_{\mathrm{r}}$ of $T$. longicornis scored highest on the second component (0.6, a moderate correlation; Meglen 1992) which consisted mostly of the same variables found in the

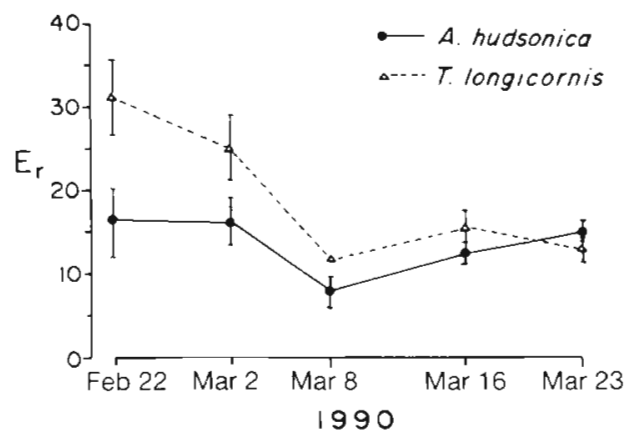

Fig. 3. Acartia hudsonica and Temora longicornis. Egg production rates $\left(E_{\mathrm{r}}\right.$ : eggs female $\left.\mathrm{d}^{-1} \mathrm{~d}^{-1}\right)$ expressed as mean $\pm 1 \mathrm{SD}$, in Long Island Sound during spring 1990. Missing confidence intervals are smaller than the height of the symbol 

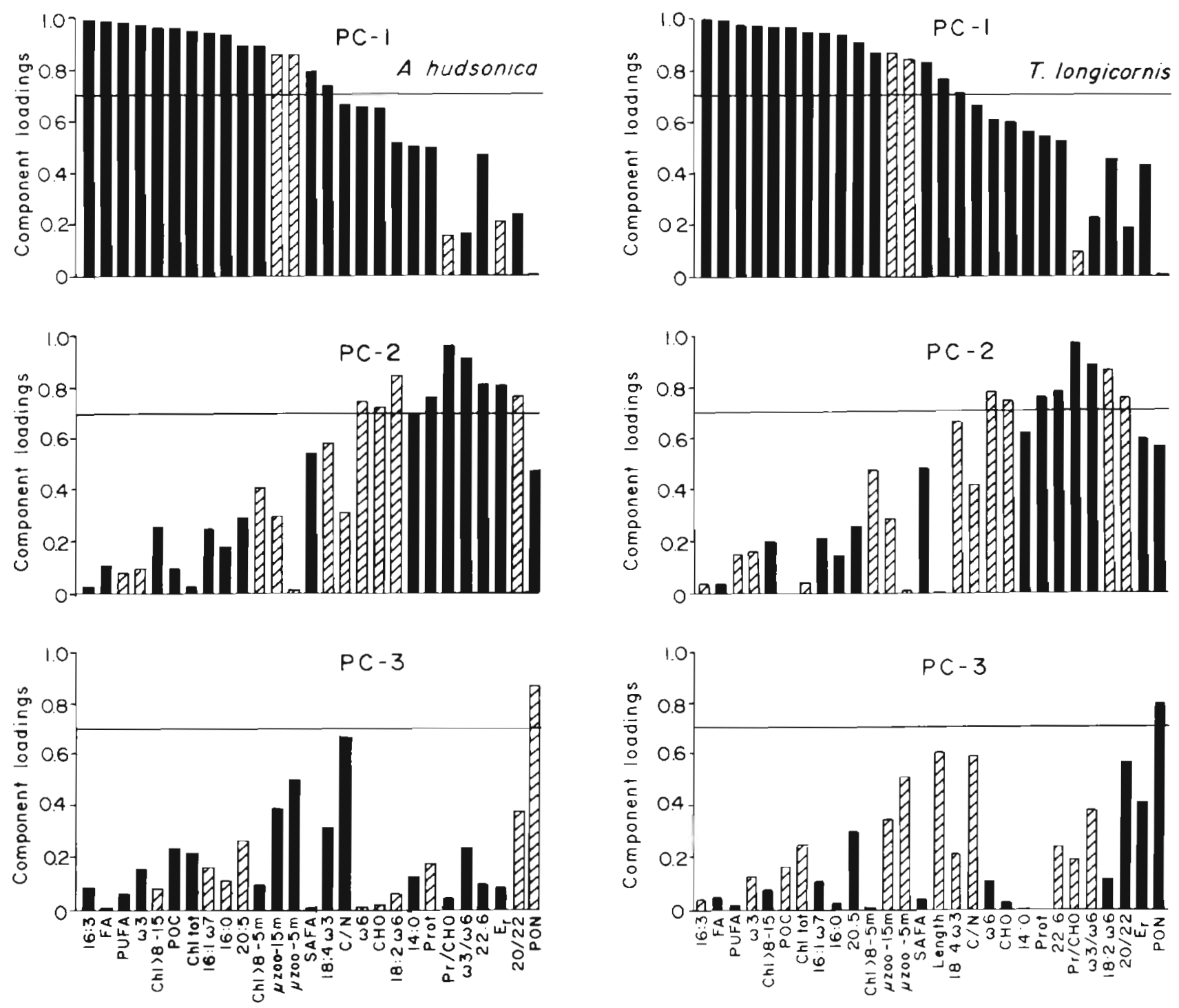

Fig. 4. Acartia hudsonica and Temora longicornis. Principal component loading of variables and $E_{\mathrm{r}}$ trom the 1990 sampling. Solid bars: positive correlation with the component; hatched bars: negative correlations. PUFA: polyunsaturated fatty acids; SAFA: saturated fatty acids

case of $A$. hudsonica, with the exception of the higher loading of the 18:403 fatty acid. The scoring of $T$. longicornis $E_{\mathrm{r}}$ on $\mathrm{PC} 1$ and $\mathrm{PC} 3$ was below 0.5 and was not significant (Meglen 1992).

\section{DISCUSSION}

The study presented in this paper investigates, in more detail than previously done, the relationship between the chemical composition of POM and in situ $E_{\mathrm{r}}$ of marine copepods. Acartia spp. are good copepod species to use in such a study because of their rapid response $(<24 \mathrm{~h})$ to the ambient food environment
(Kiørboe et al. 1985b, Tester \& Turner 1990). That is, the $E_{\mathrm{r}}$ response of Acartia spp. is likely to be correlated to factors that are measured simultaneously with the egg-production estimation. The egg-production dynamics of Temora longicornis are not as well known as they are for Acartia spp., and the measured $E_{\mathrm{r}}$ for these copepod species might be better correlated with food condition on the few days prior to capture as noted for larger copepod species at 3 to $5^{\circ} \mathrm{C}$ in Danish coastal waters (Kiørboe et al. 1985b).

The changes in the chemical composition of POM during the diatom bloom were similar to those found with nutrient depletion of aging diatom batch cultures (Thalassiosira weissflogii) in the laboratory (Jónasdót- 
tir 1994). Nitrogen and protein concentrations decreased, while $\mathrm{CHO}$ concentration increased as the bloom progressed. The lack of relative change found in the SpFA composition (Fig. 2) on the 3 sampling dates during the diatom bloom was also consistent with the lack of change found among different stages of the aging diatom culture (Jónasdóttir 1994). The protein : $\mathrm{CHO}$ and the $\mathrm{C}: \mathrm{N}$ ratios have been used as indicators of the nutrient state of phytoplankton (e.g. Kattner et al. 1983). The protein: CHO ratio in this study was about 2 to 5 times higher than other studies have reported (Sakshaug et al. 1983, Mayzaud et al. 1989), probably due to the underestimation of $\mathrm{CHO}$ by the MBTH method. The increase in the $C: N$ ratio, the decrease of the protein: $\mathrm{CHO}$ pattern and the high $\mathrm{CHO}$ and low protein concentrations of the seston also showed that the bloom and the nutrient status of POM were declining (Sakshaug et al. 1983) on the third sampling date, March 8.

$E_{\mathrm{r}}$ of both Acartia hudsonica and Temora longicornis in LIS decreased with the decline of the bloom in the same manner as maximum $E_{\mathrm{I}}$ of both $A$. hudsonica and $A$. tonsa decreased in the concurrent laboratory experiments with aging diatom cells (Jónasdóttir 1994). This observed decline in $E_{\mathrm{r}}$ while chl $a$ and particle concentrations increased indicates that the number of phytoplankton cells available as food did not control egg production. Because of the dominance of 1 phytoplankton species, Rhizosolenia sp., over the 3 sampling dates of this bloom, neither differential size (size selection) nor species composition (species selection) of the food can explain the observed pattern in $E_{\mathrm{r}}$. The slope of the carbon-chlorophyll regression line from the present study was highly significant $\left(\mathrm{R}^{2}=0.91\right)$, so carbon bound in phytoplankton (see Kiørboe et al. 1985a, White \& Roman 1992) was constant throughout the study. Thus, in the same manner as for chl concentration, phytoplankton carbon was at the maximum when $E_{\mathrm{r}}$ were at a minimum. This indicates that the quality of the phytoplankton carbon was not sufficient for egg production and that carbon concentration is not the most important food characteristic for explaining variation in egg production. It obviously makes a difference to the copepod if the carbon is bound in refractory compounds or in SpFA or other labile carbon compounds in the food. All of this suggests that changes in specific chemical components of the cells might be more important in controlling $E_{\mathrm{r}}$.

The results from this study show interesting correlations between the egg production of both Acartia hudsonica and Temora longicornis and some of the specific chemical components of the seston (Fig. 4, Table 3). The significant correlations of protein, $\mathrm{CHO}$ (CHO negatively) and protein: $\mathrm{CHO}$ ratio with $E_{\mathrm{r}}$ of $A$. hudsonica are in total agreement with laboratory observations conducted concurrently with these experiments (Jónasdóttir 1992, 1994). Additionally, similar to observations in the laboratory studies, the 20:5 to 22:6 fatty acid ratio gave a highly significant negative correlation with $E_{\mathrm{r}}$ of $A$. hudsonica, and the $\omega 3: \omega 6$ ratio, which affected $E_{r}$ of $A$. tonsa in the laboratory experiments, had a highly significant positive correlation with $E_{r}$ of A. hudsonica in the field. The $\omega 3: \omega 6$ ratio has been suggested as an important indicator in metabolic, growth and reproduction processes in crustaceans (Castell 1982, Ahlgren et al. 1990, Harrison 1990). Harrison (1990) stressed that a correct proportion of $\omega 3$ and $\omega 6$ fatty acid types might be crucial for positive growth and, in this case, successful egg production. The good correlation of $E_{\mathrm{r}}$ with the $\omega 3: \omega 6$ ratio both in this study and in Jónasdóttir (1994) support the idea that this ratio is important. The reason for the negative correlation of

Table 3 . Correlation matrix of regression coefficients, $r$, for variables measured during a spring bloom in Long Island Sound. $E_{\mathrm{r}}$ : egg production rates (eggs female $\mathrm{e}^{-1} \mathrm{~d}^{-1}$ ); A: Acartia hudsonica; $\mathrm{T}$ : Temora longicornis; chl: chlorophyll a concentration; Chil $>8$ : chl a $>8 \mu \mathrm{m} ; \mu \mathrm{zoO}$ : ciliate concentration; PON: particulate organic nitrogen; POC: particulate organic carbon; CHO: carbohydrate; FA: total fatty acids. Significant correlations are shown in bold type, X means that the correlation was not used in any of the models

\begin{tabular}{|c|c|c|c|c|c|c|c|c|c|c|c|c|c|}
\hline & $E_{\mathrm{r}}-\mathrm{A}$ & $E_{r}-\mathrm{T}$ & Total chl & $\mathrm{Chl}>8$ & $\mu z o o$ & PON & POC & Protein & $\mathrm{CHO}$ & FA & $\omega 6$ & 20.5 & $22: 6$ \\
\hline$E_{\mathrm{r}}-\mathrm{A}$ & 1 & & & & & & & & & & & & \\
\hline$E_{r}-T$ & X & 1 & & & & & & & & & & & \\
\hline Total chl & -0.219 & 0.187 & 1 & & & & & & & & & & \\
\hline Chl $>8$ & -0.211 & 0.304 & X & 1 & & & & & & & & & \\
\hline$\mu z o o$ & 0.149 & -0.399 & -0.699 & -0.802 & 1 & & & & & & & & \\
\hline PON & 0.230 & 0.494 & -0.232 & -0.061 & -0.504 & 1 & & & & & & & \\
\hline $\mathrm{POC}$ & -0.078 & 0.363 & 0.956 & 0.955 & -0.653 & -0.197 & 1 & & & & & & \\
\hline Protein & 0.184 & 0.427 & 0.501 & 0.450 & -0.709 & 0.507 & 0.458 & 1 & & & & & \\
\hline $\mathrm{CHO}$ & -0.571 & -0.272 & 0.684 & 0.728 & -0.491 & -0.344 & 0.576 & -0.113 & 1 & & & & \\
\hline $\mathrm{FA}$ & -0.098 & 0.425 & 0.934 & 0.984 & -0.816 & 0.028 & 0.968 & 0.546 & 0.596 & 1 & & & \\
\hline$\omega 6$ & -0.498 & $\mathrm{x}$ & X & X & X & -0.350 & 0.610 & -0.211 & 0.971 & 0.621 & 1 & & \\
\hline $20: 5$ & X & 0.590 & $x$ & $x$ & $x$ & 0.368 & 0.837 & 0.679 & 0.388 & 0.936 & $\mathrm{X}$ & 1 & \\
\hline $22: 6$ & 0.197 & 0.408 & $X$ & $x$ & $x$ & 0.275 & 0.518 & 0.950 & 0.193 & 0.529 & $x$ & $x$ & 1 \\
\hline
\end{tabular}




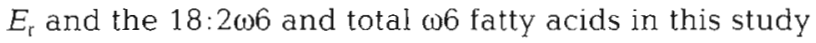
is not clear. The correlations between egg production. and the concentrations of chl, ciliates and nitrogen and the C:N ratio of the seston were all non-significant.

Temora longicornis has been found to require higher chl concentrations to obtain maximum $E_{\mathrm{r}}$ in LIS than does Acartia tonsa (Peterson \& Bellantoni 1987). This requirement for high chl concentration could explain the lower correlation on PC2 for $T$. longicornis than was found for $A$. hudsonica; the $E_{\mathrm{r}}$ of $T$. longicornis did not recover after cessation of the bloom while the $E_{\mathrm{r}}$ of A. hudsonica did. In addition, the $E_{\mathrm{r}}$ of $T$. longicornis could possibly reflect ingestion of food the day or days before the egg-production measurements as has been suggested to be the case for some larger copepods (Kiørboe et al. 1985b, Tester \& Turner 1990).

The major assumption in this study is that the females from the different sampling dates would have equal $E_{\mathrm{r}}$ if they were at the same food conditions. This includes an assumption that the females were not aging throughout the sampling time. This physiological ability to produce eggs was not measured in this study. However, the assumption is probably acceptable for the time frame of the spring sampling as the temperatures were low and Acartia tonsa females can remain actively reproducing at high rates for $\geq 31 \mathrm{~d}$ at $18^{\circ} \mathrm{C}$ (Parrish \& Wilson 1978) and $A$. clausi for $\geq 70 \mathrm{~d}$ at $2.5^{\circ} \mathrm{C}$ (Uye 1981). This indicates that at temperatures as low as $4^{\circ} \mathrm{C}, A$. hudsonica females should be reproductively active for a considerably longer time than the spring observations lasted in the present study.

\section{Path analysis - models and results}

In order to yield a better insight into how the food condition affected the egg-production rates of Acartia hudsonica and Temora longicornis during a spring bloom in 1990, 4 path analysis models, based on logical biological pathways from food to egg production were tested for both copepod species. Path analysis has a different purpose from multiple regression and PCA which are used when prediction is the main purpose of the analysis ( $\mathrm{Li}$ 1975). Path analysis is not concerned with prediction but with magnitudes and directions of interactions between variables (Sokal \& Rohlf 1981). Path analysis provides in that way a test of a plausible interpretation of the relationships between multiple variables based on a logical model structure chosen by the investigator (Sokal \& Rohlf 1981).

The underlying concept behind path analysis is that a model can be constructed that considers factors that could possibly affect the dependent or criterion variable, $Y$ Included in the model is a factor, $U_{1}$ composed of all unknown factors that could also affect variations in $Y$

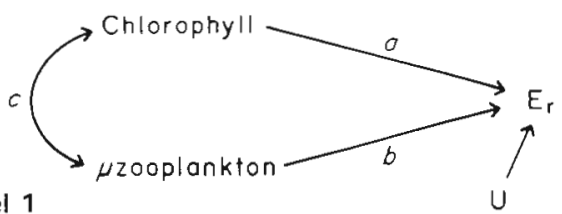

a) Model 1

U

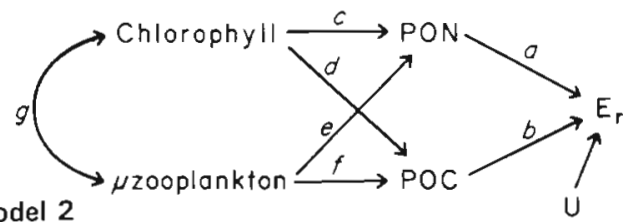

b) Model 2 U

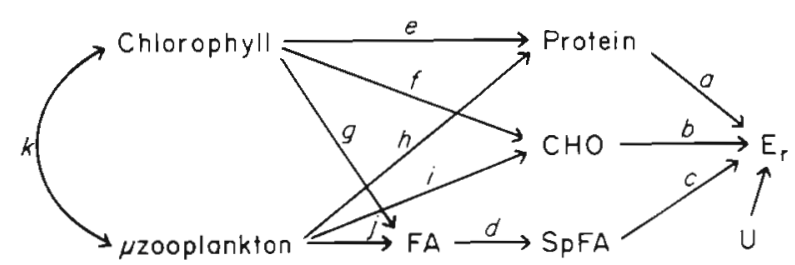

c) Model 3

d) Model 4

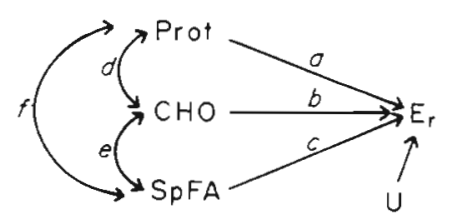

Fig. 5. Path analysis models. (a) Model 1: a plausible correlation structure among egg production and copepod food is shown. (b) Model 2: particulate organic carbon (POC) and particulate organic nitrogen ( $P O N$ ) have a causal correlation with the egg-production rates $\left(E_{\mathrm{r}}\right)$ with chlorophyll and microzooplankton as a common correlated cause. (c) Model 3: the chemical components protein, carbohydrate $(\mathrm{CHO})$ and specific fatty acids (SpFA) have a causal correlation with the eggproduction rates with chlorophyll and microzooplankton as a common correlated cause. Total fatty acids (FA) are the sole source for SpFA. (d) Model 4: chlorophyll and microzooplankton have been removed from the model. Prot: protein. The chemical components are assumed to be correlated. For all models, $U$ : all unknown factors which affect $E_{r} ; a$ to $k$ : path coefficients $p_{\mathrm{a}}$ to $p_{k}$

The total determination of the variance of $Y$ is 1 . The variance due to the unknown residual $U$ is $r_{U}{ }^{2}$, which is the coefficient of determination between $U$ and $Y$. The greater the variance of $Y$ that can be explained with the known variables, the less the unknown variance is. In other words, the goal of path analysis is to construct a logical model with the lowest $r_{U}{ }^{2}$. The strength and the importance of the relationship (positive or negative) between cause and effect variables is estimated by the path coefficients (Li 1975, Sokal \& Rohlf 1981, Loehlin 1987). The path coefficients are the standardized partial regression coefficients and are shown in the models 
(Fig. 5a to d) as $p_{i}$ where $i$ is the link between the variables. More detailed descriptions of the application of path analysis are given by Li (1975), Loehlin (1987) and Sokal \& Rohlf (1981). The equations used to solve the models tested in the present study are detailed in Jónasdóttir (1992).

In the models presented here, the criterion variable, $Y$, is the $E_{\mathrm{I}}$ of either Acartia hudsonica or Temora longicornis in LIS. The predictor variables are specific chemical components of the POM, including chl $a$ and ciliate concentrations.

As an initial condition in the models, microzooplankton (ciliates) and chl a concentrations (both total and $>8 \mu \mathrm{m}$ ) were assumed to be correlated. This is indicated by double-headed arrows (correlated causes) between these variables in the models (e.g. Fig. 5a). This assumption is reasonable since ciliates can remove a significant proportion of the primary production (Caron et al. 1989, Tiselius 1989, Whyte \& Nagata 1990). The $\mathrm{R}^{2}$ for the correlations between chl $a$ and ciliate concentrations were 0.49 and 0.73 for total chl a and chl a $>8 \mu \mathrm{m}$, respectively. Both correlations were highly significant $(\mathrm{p}<0.001)$ and negative (see Table 3 which lists the regression coefficients, $r$ ).

The computer program Mathematica ${ }^{\mathrm{TM}}$ for Macintosh computers was used to solve the equations for the different models. The correlation matrices of the standardized regression coefficients needed to calculate the path coefficients are shown in Table 3. Non-significant correlation coefficients were set to zero in the calculations. The results from the different models are given in Tables 4 \& 5 and include the path coefficients (the strength or importance of each path) and the unknown residual $r_{U}^{2}$ calculated for each model.

Model 1 (Fig. 5a), the simplest model tested, was based on the correlations most often investigated in egg-production field studies, namely, chl a (see e.g. Checkley 1980, Durbin et al. 1983, Runge 1985b, Peterson et al, 1991) and microzooplankton concentrations (Stoecker \& Egloff 1987, Tiselius 1989, Kleppel et al. 1991). The model was tested using both total chl a and chl $a>8 \mu \mathrm{m}$ and resulted in $100 \%$ of the variation in $E_{\mathrm{r}}$ of both Acartia hudsonica and Temora longicornis unexplained (Table 4).

Table 4. Path coefficients for models 1 and 2. Abbreviations as in Table 3. Acartia: Acartia hudsonicis Temora: Temora longicornis

\begin{tabular}{|c|c|c|c|c|c|c|}
\hline $\begin{array}{l}\text { Copepod: } \\
\text { Chil size: }\end{array}$ & $\begin{array}{l}\text { Runs } 1-1 \& 1-2 \\
\text { Acartia } \\
\text { Chl total \& }>8\end{array}$ & $\begin{array}{c}\text { Runs } 1-3 \& 1-4 \\
\text { Temora } \\
\text { Chl total \& }>8\end{array}$ & $\begin{array}{l}\text { Run 2-1 } \\
\text { Acartia } \\
\text { ChI total }\end{array}$ & $\begin{array}{l}\text { Run 2-2 } \\
\text { Acartia } \\
\text { Chl }>8\end{array}$ & $\begin{array}{c}\text { Run 2-3 } \\
\text { Temora } \\
\text { Total chl }\end{array}$ & $\begin{array}{l}\text { Run } 2-4 \\
\text { Temora } \\
\text { Chl }>8\end{array}$ \\
\hline Chl- $E_{\mathrm{r}}$ & 0.000 & 0.000 & - & -- & - & - \\
\hline$\mu z o o-E_{\mathrm{r}}$ & 0.000 & 0.000 & & - & - & - \\
\hline PON-E & - & - & 0.000 & 0.000 & 0.494 & 0.507 \\
\hline POC-E & - & - & 0.000 & 0.000 & 0.007 & 0.081 \\
\hline Chl-PON & - & - & -0.689 & -1.133 & -0.689 & -1.133 \\
\hline Chl-POC & - & - & 0.977 & 1.209 & 0.977 & 1.209 \\
\hline$\mu z O 0-P O N$ & - & - & -0.985 & -1.413 & -0.985 & -1.413 \\
\hline$\mu z o o-P O C$ & - & - & -0.030 & 0.316 & -0.030 & 0.316 \\
\hline$r_{U}^{2}$ & 1.000 & 1.000 & 1.000 & 1.000 & 0.756 & 0.736 \\
\hline
\end{tabular}

Table 5. Path coefficients for models 3 and 4. Abbreviations as in Table 3. Acartia: Acartia hudsonicis; Temora: Temora longiCornis; SpFA: specific fatty acids

\begin{tabular}{|c|c|c|c|c|c|c|c|c|}
\hline $\begin{array}{r}\text { Copepod: } \\
\text { Chl size: } \\
\text { SpFA: }\end{array}$ & $\begin{array}{c}\text { Run 3-1 } \\
\text { Acartia } \\
\text { Total chl } \\
\omega 6\end{array}$ & $\begin{array}{c}\text { Run 3-2 } \\
\text { Acartia } \\
\text { Chl }>8 \\
\omega 6\end{array}$ & $\begin{array}{c}\text { Run 3-2 } \\
\text { Acartia } \\
\text { Chl }>8 \\
22: 6\end{array}$ & $\begin{array}{c}\text { Run 3-4 } \\
\text { Temora } \\
\text { Total chl } \\
20: 5\end{array}$ & $\begin{array}{c}\text { Run 3-5 } \\
\text { Temora } \\
\text { Chl > } \\
20: 5\end{array}$ & $\begin{array}{c}\text { Run 3-6 } \\
\text { Temora } \\
\text { Chl. }>8 \\
22: 6\end{array}$ & $\begin{array}{c}\text { Run 4-1 } \\
\text { Acartia } \\
- \\
\omega 6\end{array}$ & $\begin{array}{c}\text { Run } 4-2 \\
\text { Temora } \\
- \\
20.5\end{array}$ \\
\hline Protein- $E_{\mathrm{r}}$ & 0.365 & 0.246 & 0.138 & 0.273 & 0.289 & 0.471 & 0.000 & 0.050 \\
\hline $\mathrm{CHO}-E_{r}$ & -0.484 & -0.401 & -0.616 & -0.435 & -0.432 & -0.071 & -1.530 & 0.000 \\
\hline$S p F A-E_{r}$ & -0.540 & -0.518 & -0.034 & 0.563 & 0.547 & -0.109 & 0.987 & 0.557 \\
\hline Chl-protein & 0.011 & -0.332 & -0.332 & 0.011 & -0.332 & -0.332 & - & - \\
\hline Chl-CHO & 0.666 & 0.937 & 0.937 & 0.666 & 0.937 & 0.937 & - & - \\
\hline Chl-FA & 0.711 & 0.924 & 0.924 & 0.711 & 0.924 & 0.924 & - & - \\
\hline$\mu z o o$-protein & -0.702 & -0.976 & -0.976 & -0.702 & -0.976 & -0.976 & - & - \\
\hline$\mu z O O-C H O$ & -0.025 & 0.260 & 0.260 & -0.025 & 0.260 & 0.260 & - & - \\
\hline$\mu z o o-F A$ & -0.319 & -0.075 & -0.075 & -0.319 & -0.075 & -0.075 & - & - \\
\hline$r_{U}^{2}$ & 0.167 & 0.107 & 0.609 & 0.211 & 0.215 & 0.831 & 0.759 & 0.651 \\
\hline
\end{tabular}


In Model 2 (Fig. 5b), POC and PON were added into the pathway since POC and PON concentrations as well as $C: N$ ratios are frequently used in field studies to demonstrate quality of food (e.g. Durbin et al. 1983, Ambler 1986, Kleppel 1992). Chl a and microzooplankton concentrations were set as common correlated causes for POC and PON, i.e. both chl $a$ and microzooplankton cause variations in POC and PON and are themselves correlated with each other. This model was not an improvement over Model 1 for Acartia hudsonica, as it did not provide a better explanation for the variance in $E_{\mathrm{r}}$ (Table 4 ). In testing the Temora longicornis data, $75 \%$ and $74 \%$ of the variance in $E_{\mathrm{r}}$ remained unexplained using total chl $a$ and chl $a$ $>8 \mu \mathrm{m}$ respectively (Table 4 ). Carbon and nitrogen content of POM did not explain the observed variance in the $E_{\mathrm{r}}$ of the copepods in these models.

Model 3 (Fig. 5c), the most complete of the 4 models, most closely approximates the conditions of the field study described here as it incorporates protein, $\mathrm{CHO}$ and SpFA from 2 common and correlated sources, namely, chl $a$ and microzooplankton. Three different SpFA were tested in the model: $\omega 6$ and 22:6\%3 in the case of Acartia hudsonica, and 20:5 Temora longicornis. These fatty acids were chosen as they exhibited the best correlation with $E_{\mathrm{r}}$ of both species based on principal component analysis. The total fatty acid pool was the sole source of SpFA in this model. The results from this model showed a large increase in the explainable variance (Table 5). In the case of $E_{\mathrm{r}}$ of $A$. hudsonica for both total and $>8 \mu \mathrm{m}$ chl $a$, the unexplained variance, $r_{U}{ }^{2}$, decreased to $60 \%$ when the 22:603 fatty acid was used and as low as $11 \%$ in the case of the $\omega 6$ fatty acid. For T. Iongicornis, only $17 \%\left(r_{U}{ }^{2}=0.83\right)$ of the variance was explained when the 22:6003 fatty acid was used but $79 \%\left(r_{U}{ }^{2}=\right.$ 0.21 ) when the 20:5 33 fatty acid was used.

Model 4, a variation of Model 3, was run in order to test the effect of excluding $\mathrm{chl}$ a and microzooplankton concentrations as factors in the system (Fig. 5d). This model included all protein, $\mathrm{CHO}$ and fatty acids, without restricting their source to phytoplankton or microzooplankton. Protein, $\mathrm{CHO}$ and SpFA concentrations were all assumed to be correlated causes for egg production. Only the SpFA which gave the best results in Model 3 were used in Model 4 . Over $60 \%$ of the variance in $E_{\mathrm{r}}$ of both copepod species was unexplained using this model (Table 5).

The path analysis models point out the importance of chl $a$ and microzooplankton concentrations in explaining the observed $E_{\mathrm{r}}$ during the 1990 spring bloom in LIS despite the fact that neither $E_{\mathrm{r}}$ and chl a nor $E_{\mathrm{r}}$ and ciliates were correlated. Model 1 showed that chl $a$ and ciliate concentrations alone could not explain any of the observed variance in $E_{\mathrm{r}}$ of either Acartia hudsonica or Temora longicornis. However, when chl a and ciliate concentrations were totally excluded from the model (Model 4), the chemical components alone could not explain the variation in $E_{\mathrm{r}}$ ( 24 and $35 \%$ of the variance explained). Model 4 included all sources of protein, $\mathrm{CHO}$ and fatty acids, but some fraction of these compound classes may have originated from non-food sources. When the source of these chemical components was limited to the living particles, i.e. chl a and ciliates (Model 3), the best explanation of the variance in $E_{\mathrm{r}}$ was achieved. The main difference between Models 3 and 4 is that the correlation coefficients between the different chemical components were decomposed into more factors in Model 3 than in Model 4. Individually, the correlations between these 3 chemical components of the seston were not strong. However, when the strong correlations between some of these components and the potential food sources (chl a and ciliates) were added to the structure of the model, the additional paths generated aided in explaining the variance.

From the results of Model 3 (Runs 3-1,3-2, 3-4, and 3-5; Table 5) it can be seen that the importance of phytoplankton in influencing $E_{\mathrm{r}}$ of both copepod species results mainly from a strong relationship (high path coefficient) with total fatty acids and CHO. The model demonstrates that the combined negative effect of carbohydrate and the $\omega 6$ fatty acid on $E_{\mathrm{r}}$ of Acartia hudsonica can explain a large fraction of the variance in the observed egg-production rate. For Temora longicornis, the importance of the 20:5 13 fatty acid, which is characteristic of diatoms, combined with the negative effect of $\mathrm{CHO}$, was able to explain most of the variance in $E_{\mathrm{r}}$ (see Runs $3-4$ and $3-5$; Table 5). The effects of ciliates are seen primarily through the negative relations with protein (see Table 5).

Another important factor in the models shown here is the inclusion of SpFA. The choice of a particular SpFA. is critical to explaining the observed $E_{\mathrm{r}}$ of the copepod species of interest. A change in the SpFA can significantly increase $r_{U}^{2}$, as demonstrated in Runs 3-2, 3-3, 3-5 and 3-6 (Table 5).

It is important to remember that the results of the path analysis models presented here are limited to conditions during this 1990 spring bloom in LIS. For example, temperature, which often has been found to affect $E_{\mathrm{r}}$ (McLaren 1965, Uye 1981, Kleppel 1992), and female size were not included in these models as these factors did not significantly change throughout the study.

The correlation observed between PON and egg production in previous studies is most likely due to the association of nitrogen with the protein content of the food rather than nitrogen content per se. In this study, the correlation between protein and PON was significant $\left(R^{2}=0.257\right)$ but low. Similarly, a low correlation 
between PON and protein could account for the inconsistency in correlations between PON and $E_{\mathrm{r}}$ in previous field studies (e.g. correlation: Durbin et al. 1983, Kleppel 1992; no correlation: Checkley 1980). That is, if the correlation between protein and PON is high, the correlation between $E_{r}$ and PON is good, but if the correlation between protein and PON is poor or merely good, no correlation between $E_{\mathrm{r}}$ and PON is observed.

The results of the path analyses presented here may also explain why some studies do not find correlations with $E_{\mathrm{r}}$ and concentrations of phytoplankton and microzooplankton while other studies do. That is, when one or more important chemical components of the seston do not vary much, it is likely that the concentrations of phytoplankton and microzooplankton control the $E_{\mathrm{r}}$ of copepods. However, when important chemical components vary sufficiently, both the concentration and the chemical composition of the food may control the $E_{\mathrm{r}}$ of copepods.

The limitation of path analysis is the requirement for linearity. As a result, significant nonlinear relationships such as those between $E_{t}$ and the 22:6w3 and $E_{\mathrm{r}}$ and protein did not emerge as important in path analysis. Therefore, the 2 analyses, PCA and path analysis, complemented each other in this study. The application of the method of path analysis to data sets such as the one described in this paper in combination with conventional correlation statistics can increase the understanding of interactions among variables in the data set. The dynamics of $E_{\mathrm{r}}$ of Acartia hudsonica and Temora longicornis in LIS were not apparent when linear relationships alone were investigated. However, the set of 4 models used to describe plausible relationships among the variables measured in this study (Fig. 5) were useful in describing reasonable explanations of the dynamics of the system. It is also clear from these models that prediction of $E_{\mathrm{r}}$ of copepods in the field is not dependent on a single or a few components but a combination of indirect and direct causal paths which all affect the ability of the female copepod to produce eggs.

Acknowledgements. This study was supported by the Marine Sciences Research Center and research grants from NATO and Sigma-Xi grant-in-aid of research awarded to S.H.J. and by Hudson River Fundation, Grant HRF no. 012/90A/032 awarded to D. J. Lonsdale and E. M. Cosper. We thank B. Zilenski for assistance during the field sampling, $M$. de Angelis for drafting and editing the manuscript, S. Wakeham for the use of his laboratory for fatty acid analysis and Uwe Timm for mathematical assistance. S.H.J. is grateful to Dr D. J. Lonsdale for her support and advice throughout this study. D. J. Lonsdale, E. M. Cosper, C. Lee, W. T. Peterson and M. R. Roman are gratefully acknowledged for their comments on an earlier version of this paper and 3 anonymous reviewers for their helpful suggestions. This is Contribution No. 981 from the Marine Sciences Research Center, SUNY at Stony Brook, New York.

\section{LITERATURE CITED}

Ahlgren, G., Lundstedt, L., Brett, M., Forsberg, C. (1990). Lipid composition and food quality of some freshwater phytoplankton for cladoceran zooplankters. J. Plankton Res. 12: 809-818

Ambler, J. W. (1986). Effect of food quantity and quality on egg production of Acartia tonsa Dana from East Lagoon, Galveston, Texas. Estuar. coast. Shelf Sci. 23: 183-196

Burney, C. M., Sieburth, J. McN. (1977). Dissolved carbohydrates in seawater. II, A spectrophotometric procedure for total carbohydrate analysis and polysaccharide estimation. Mar. Chem. 5: 15-28

Caron, D. A., Lim, E. L., Kunze, H., Cosper, E. M., Anderson, D. M. (1989). Trophic interactions between nano- and microzooplankton and the 'brown tide'. In: Cosper, E. M., Bricelj, M., Carpenter, E. J. (eds.) Novel phytoplankton blooms: causes and impacts of recurrent brown tides and other unusual blooms. Springer-Verlag, Berlin, p. 265-294

Castell, J. D. (1982) Fatty acid metabolism in crustaceans. In: Pruder, G. D., Langdon, C., Conklin, D. (eds.) Proceedings of the second international conference on aquaculture nutrition: biochemical and physiological approaches to shellfish nutrition. Louisiana State University, Baton Rouge, p. $124-145$

Checkley, D. M. Jr (1980). Food limitation of egg production by a marine, planktonic copepod in the sea off southern California. Limnol. Oceanogr. 25: 991-998

Conklin, D. E., Provasoli, L. (1977). Nutritional requirements of the water flea Moina macrocopa. Biol. Bull. mar. biol. Lab., Woods Hole 152: $337-350$

Dadd, R. H. (1982). Insect nutrition: relevance to marine invertebrates. In: Pruder, G. D., Langdon, C., Conklin, D. (eds.) Proceedings of the second international conference on aquaculture nutrition: biochemical and physiological approaches to shellfish nutrition. Louisiana State University, Baton Rouge, p. 33-55

Durbin, E. G., Durbin, A. G., Campbell, R. G. (1992). Body size and egg production in the marine copepod Acartia hudsonica during a winter-spring diatom bloom in Narragansett Bay. Limnol. Oceanogr. 37: 342--360

Durbin, E. G., Durbin, A. G., Smayda, T J., Verity, P. G. (1983). Food limitation of production by adult Acartia tonsa in Narragansett Bay, Rhode Island. Limnol. Oceanogr. 28: 1199-1213

Harrison, K. E. (1990). The role of nutrition in maturation, reproduction and embryonic development of decapod crustaceans: a review. J. Shellfish Res. 9: 1-28

Johnson, K. M., Burney, C. M., Sieburth, J. McN. (1981). Doubling the production and precision of the $\mathrm{MBTH}$ spectrophotometric assay for dissolved carbohydrates in seawater. Mar. Chem. 10:467-473

Johnson, K. M., Sieburth, J. McN. (1977). Dissolved carbohydrates in seawater. I. A precise spectrophotometric analysis for monosaccharides. Mar. Chem. 5: 1-13

Jónasdóttir, S. H. (1992). Chemical composition of food and the reproductive success of the copepods Acartia tonsa, Acartia hudsonica and Temora longicornis. Ph.D. dissertation, State University of New York at Stony Brook.

Jónasdóttir, S. H. (1994). Effects of food quality on the reproductive success of Acartia tonsa and Acartia hudsonica: laboratory observations. Mar. Biol. 121:67-81

Kattner, G., Gercken, G., Eberlein, K. (1983). Development of lipids during a spring plankton bloom in the northern North Sea. I. Particulate fatty acids. Mar. Chem. 14: $149-162$

Kiørboe, T., Møhlenberg, F., Hamburger, K. (1985a). Bioener- 
getics of the planktonic copepod Acartia tonsa: relation between feeding, egg production and respiration, and composition of specific dynamic action. Mar. Ecol. Prog. Ser. 26: 85-97

Kiørboe, T., Møhlenberg, F., Riisgård, H. U. (1985b). In situ feeding rates of planktonic copepods: a comparison of four methods. J. exp. mar. Biol. Ecol. 88: 67-81

Kiørboe, T., Nielsen, T G. (1994). Regulation of zooplankton biomass and production in a temperate, coastal ecosystem. 1. Copepods. Limnol. Oceanogr. 39: 493-507

Kleppel, G. S. (1992). Environmental regulation of feeding and egg production by Acartia tonsa off southern California. Mar. Biol. 112: 57-65

Kleppel, G. S., Holliday, D. V., Pieper, R. E. (1991). Trophic interactions between copepods and microplankton: a question about the role of diatoms. Limnol. Oceanogr. 36: $172-178$

Li, C. C. (1975). Path analysis - a primer. The Boxwood Press, Pacific Grove, CA

Loehlin, J. C. (1987). Latent variable models. An introduction to factor, path, and structural analysis. Lawrence Erlbaum Associates, Hillsdales, NJ

Mayzaud, P., Chanut, J. P., Ackman, R. G. (1989). Seasonal changes of the biochemical composition of marine particulate matter with special reference to fatty acids and sterols. Mar. Ecol. Prog. Ser. 56: 189-204

McLaren, I. A. (1965). Some relationships between temperature and egg size, body size, development rate, and fecundity, of the copepod Pseudocalanus. Limnol. Oceanogr. 10: $528-538$

Meglen, R. R. (1992). Examining large databases: a chemometric approach using principal component analysis. Mar. Chem. 39: 217-237

Morris, R. J., McCartney, M. J., Robinson, G. A. (1983). Studies of a spring phytoplankton bloom in an enclosed experimental ecosystem. I. Biochemical changes in relation to the nutrient chemistry of water. J. exp. mar. Biol. Ecol. 70 : $249-262$

Parrish, K. K., Wilson, D. F. (1978). Fecundity studies on Acartia tonsa (Copepoda: Calanoida) in standardized culture. Mar. Biol. 46: 65-81

Peltzer, E. T., Alford, J. B., Gagosian, R. B. (1984). Methodology for sampling and analysis of lipids in aerosols from the remote marine atmosphere. Tech. Rep. Woods Hole oceanogr. Inst. WHOI-84-9: 1-104

Peterson, W. T., Bellantoni, D. C. (1987). Relationships between water-column stratification, phytoplankton cell size and copepod fecundity in Long Island Sound and off central Chile. S. Afr. J. mar. Sci. 5: 411-420

Peterson, W. P., Tiselius, P., Kiørboe, T. (1991). Copepod egg production, moulting and growth rates, and secondary

This article was submitted to the editor production, in the Skagerrak in August 1988. J. Plankton Res. 13: 131-154

Runge, J. A. (1985a). Egg production rates of Calanus finmarchicus in the sea off Nova Scotia. Arch. Hydrobiol. 21: $33-40$

Runge, J. A. (1985b). Relationship of egg production of Calanus pacificus to seasonal changes in phytoplankton availability in Puget Sound, Washington. Limnol. Oceanogr. 30: 382-396

Sakshaug, E., Andersen, K., Myklestad, S., Olsen, Y (1983). Nutrient status of phytoplankton communities in Norwegian waters (marine, brackish, and fresh) as revealed by their chemical composition. J. Plankton Res. 5: 175-196

Smith, P. K., Krohn, R. I., Hermanson, G. T., Mallia, A. K., Gartner, F. H., Provenzano, M. D., Fujimoto, E. K., Goeke, N. M., Olson, B. J., Klenk, D. C. (1985). Measurement of protein using bicinchoninic acid. Analyt. Biochem. 150: $76-85$

Sokal, R. R., Rohlf, F. J. (1981). Bionetry. The principles and practice of statistics in biological research, 2 nd edn. W. H. Freeman \& Co., New York

Stearns, D. E., Tester, P. A., Walker, R. L. (1989). Diel changes in the egg production rate of Acartia tonsa (Copepoda, Calanoida) and related environmental factors in two estuaries. Mar. Ecol. Prog. Ser. 52: 7-16

Stoecker, D. K., Egloff, D. A. (1987). Predation by Acartia tonsa Dana on planktonic ciliates and rotifers. J. exp. mar. Biol. Ecol. 110: 53-68

Tester, P. A., Turner, J. T (1990). How long does it take copepods to make eggs? J. exp. mar. Biol. Ecol. 141: 169-182

Tiselius, P. (1989). Contribution of aloricate ciliates to the diet of Acartia clausi and Centropages hamatus in coastal waters. Mar. Ecol. Prog. Ser. 56: 49-56

Uye, S. (1981). Fecundity studies of neritic calanoid copepods Acartia clausi Giesbrecht and A. steueri Smimov: a simple empirical model of daily egg production. J. exp. mar. Biol. Ecol. 50: 255-271

Wakeham, S. G., Canuel, E. A. (1990). Fatty acids and sterols of particulate matter in a brackish and seasonally anoxic coastal salt pond. Org. Geochem. 16: 703-713

Weissman, P., Lonsdale, D. J., Yen, J. (1993). The effect of peritrich ciliates on the production of Acartia hudsonica in Long Island Sound. Limnol. Oceanogr. 38: 613-622

White, J. R., Roman, M. R. (1992). Egg production by the calanoid copepod Acartia tonsa in the mesohaline Chesapeake Bay: the importance of food resources and temperature. Mar. Ecol. Prog. Ser. 86: 239-249

Whyte, J. N. C., Nagata, W. D. (1990). Carbohydrate and fatty acid composition of the rotifer, Brachionus plicatilis, fed monospecific diets of yeast or phytoplankton. Aquaculture 89: $263-272$

Manuscript first received: March 16, 1994

Revised version accepted: December 14, 1994 